
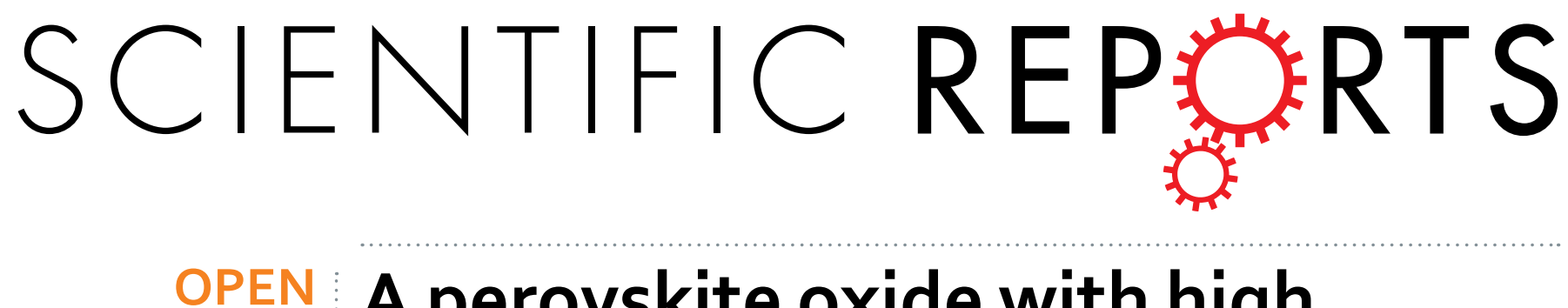

\title{
A perovskite oxide with high conductivities in both air and reducing atmosphere for use as electrode for solid oxide fuel cells
}

Received: 20 April 2016

Accepted: 26 July 2016

\author{
Rong Lan ${ }^{1}$, Peter I. Cowin ${ }^{2}$, Sivaprakash Sengodan ${ }^{1} \&$ Shanwen Tao ${ }^{1,3}$
}

Electrode materials which exhibit high conductivities in both oxidising and reducing atmospheres are in high demand for solid oxide fuel cells (SOFCs) and solid oxide electrolytic cells (SOECs). In this paper, we investigated Cu-doped $\mathrm{SrFe}_{0.9} \mathrm{Nb}_{0.1} \mathrm{O}_{3-\delta}$ finding that the primitive perovskite oxide $\mathrm{SrFe} \mathrm{e}_{0.8} \mathrm{Cu}_{0.1} \mathrm{Nb}_{0.1} \mathrm{O}_{3-\delta}$ (SFCN) exhibits a conductivity of $63 \mathrm{Scm}^{-1}$ and $60 \mathrm{Scm}^{-1}$ at $415^{\circ} \mathrm{C}$ in air and $5 \% \mathrm{H}_{2} / \mathrm{Ar}$ respectively. It is believed that the high conductivity in $5 \% \mathrm{H}_{2} / \mathrm{Ar}$ is related to the exsolved $\mathrm{Fe}$ (or FeCu alloy) on exposure to a reducing atmosphere. To the best of our knowledge, the conductivity of $\mathrm{SrFe}_{0.8} \mathrm{Cu}_{0.1} \mathrm{Nb}_{0.1} \mathrm{O}_{3-\delta}$ in a reducing atmosphere is the highest of all reported oxides which also exhibit a high conductivity in air. Fuel cell performance using $\mathrm{SrFe}_{0.8} \mathrm{Cu}_{0.1} \mathrm{Nb}_{0.1} \mathrm{O}_{3-\delta}$ as the anode, $\left(\mathrm{Y}_{2} \mathrm{O}_{3}\right)_{0.08}\left(\mathrm{ZrO}_{2}\right)_{0.92}$ as the electrolyte and $\mathrm{La}_{0.8} \mathrm{Sr}_{0.2} \mathrm{FeO}_{3-\delta}$ as the cathode achieved a power density of $423 \mathrm{mWcm}^{-2}$ at $700^{\circ} \mathrm{C}$ indicating that $\mathrm{SFCN}$ is a promising anode for SOFCs.

Solid oxide fuel cells (SOFCs) are electrochemical devices used to convert chemical energy into electricity with a very high efficiency ${ }^{1}$. Symmetrical fuel cells have the potential application to be used as reversible SOFCs, which can operate in both fuel cell and electrolyser modes. In a recent report, it was found that a much better stability can be achieved by SOFCs which operate in both SOFC and solid oxide electrolytic cell (SOEC) modes (reversible SOFC) $)^{2}$. For reversible SOFCs, the use of a symmetrical electrode such as $\left(\mathrm{La}_{0.75} \mathrm{Sr}_{0.25}\right) \mathrm{Cr}_{0.5} \mathrm{Mn}_{0.5} \mathrm{O}_{3-\delta}$ (LSCM) would be an ideal solution ${ }^{3-5}$. An essential requirement of the electrode material is that it must exhibit a high conductivity in both air and fuel conditions at the fuel cell operating temperature. Therefore, electrode materials exhibiting high conductivities in both oxidising and reducing atmospheres are in high demand for solid oxide fuel cells (SOFCs) and solid oxide electrolytic cells (SOECs), particularly for symmetrical SOFCs.

There are plenty oxide materials which exhibit high conductivity in air. The real challenge is to identify a good stable oxide anode material exhibiting high conductivity in a reducing atmosphere ${ }^{5,6}$. Several redox stable mixed oxide-ion electronic conductors have been developed as ceramic anode materials for SOFCs, such as $\left(\mathrm{La}_{0.75} \mathrm{Sr}_{0.25}\right)$ $\mathrm{Cr}_{0.5} \mathrm{Mn}_{0.5} \mathrm{O}_{3-\delta}(\mathrm{LSCM})^{7}, \mathrm{Sr}_{2} \mathrm{MgMoO}_{6-\delta}\left(\mathrm{SMMO}^{8}, \mathrm{La}_{4} \mathrm{Sr}_{8} \mathrm{Ti}_{11} \mathrm{Mn}_{0.5} \mathrm{Ga}_{0.5} \mathrm{O}_{37.5}\right.$ (LSTMG) ${ }^{9}, \mathrm{La}_{0.8} \mathrm{Lr}_{0.2} \mathrm{Sc}_{0.2} \mathrm{Mn}_{0.8} \mathrm{O}_{3-\delta}$ (LSSM $)^{10}, \mathrm{La}_{0.7} \mathrm{Ca}_{0.3} \mathrm{CrO}_{3-\delta}{ }^{11}, \mathrm{Sr}_{2} \mathrm{Fe}_{1.5} \mathrm{Mo}_{0.5} \mathrm{O}_{6-\delta}{ }_{-\delta, 13}^{12,} \mathrm{Pr}_{0.8} \mathrm{Sr}_{1.2}(\mathrm{Co}, \mathrm{Fe})_{0.8} \mathrm{Nb}_{0.2} \mathrm{O}_{4+\delta} / \mathrm{CoFe}$ alloy ${ }^{14}, \mathrm{PrBaMn}_{2} \mathrm{O}_{5+\delta}{ }^{15}$, $\mathrm{La}_{0.33} \mathrm{Sr}_{0.67} \mathrm{Ti}_{0.33} \mathrm{Mn}_{0.67} \mathrm{O}_{3-\delta}(\mathrm{LSTM})^{16}, \mathrm{Ce}_{0.6} \mathrm{MN}_{0.3} \mathrm{Fe}_{0.1} \mathrm{O}_{2}-\mathrm{La}_{0.6} \mathrm{Sr}_{0.4} \mathrm{Fe}_{0.9} \mathrm{Mn}_{0.1} \mathrm{O}_{3}$ (CMF-LSFM) ${ }^{17}$. All of these oxides or composite anodes are redox stable or redox reversible. However, except for La-doped $\mathrm{SrTiO}_{3}$, the conductivity at the anode is typically below $30 \mathrm{~S} / \mathrm{cm}$. The anode conductivity needs to be further improved, particularly for tubular SOFCs with a long pathway for electrons. The conductivity of La-doped $\mathrm{SrTiO}_{3}$ in a reducing atmosphere is high if pre-reduced at a high temperature. However, the conductivity of doped $\mathrm{SrTiO}_{3}$ in air is generally less than $0.1 \mathrm{~S} / \mathrm{cm}^{6,9,18}$. In reported perovskite oxides, besides LSCM, The double perovskite $\mathrm{Sr}_{2} \mathrm{Fe}_{1.5} \mathrm{Mo}_{0.5} \mathrm{O}_{6-\delta}$ (SFMO), was demonstrated to be a good electrode for symmetrical SOFCs ${ }^{12,13}$. However, the conductivity of SFMO under the SOFC anode environment is not very high thus further improvements are required ${ }^{13}$. On the other hand, a promising family of redox stable anodes for SOFCs is B-site doped $\mathrm{SrFeO}_{3-\delta}$. It has been reported that $\mathrm{SrFe}_{1-\mathrm{x}} \mathrm{Ti}_{\mathrm{x}} \mathrm{O}_{3-\delta}$ where $\mathrm{x}=0.3,0.4$ combined with $\mathrm{Ce}_{0.9} \mathrm{Gd}_{0.1} \mathrm{O}_{2-\delta}$ performs well as an anode for SOFCs ${ }^{19}$. It was found that $\mathrm{SrFe}_{0.9} \mathrm{Ti}_{0.1} \mathrm{O}_{3-\delta}$ is redox stable with a conductivity of $2.53 \mathrm{~S} / \mathrm{cm}$ at $600^{\circ} \mathrm{C}$ in a reducing atmosphere ${ }^{20}$.

${ }^{1}$ School of Engineering, University of Warwick, Coventry CV4 7AL, UK. ${ }^{2}$ Department of Chemical and Process Engineering, University of Strathclyde, Glasgow G1 1XJ, UK. ${ }^{3}$ Department of Chemical Engineering, Monash University, Clayton, Victoria 3800, Australia. Correspondence and requests for materials should be addressed to S.T. (email: S.Tao.1@warwick.ac.uk) 

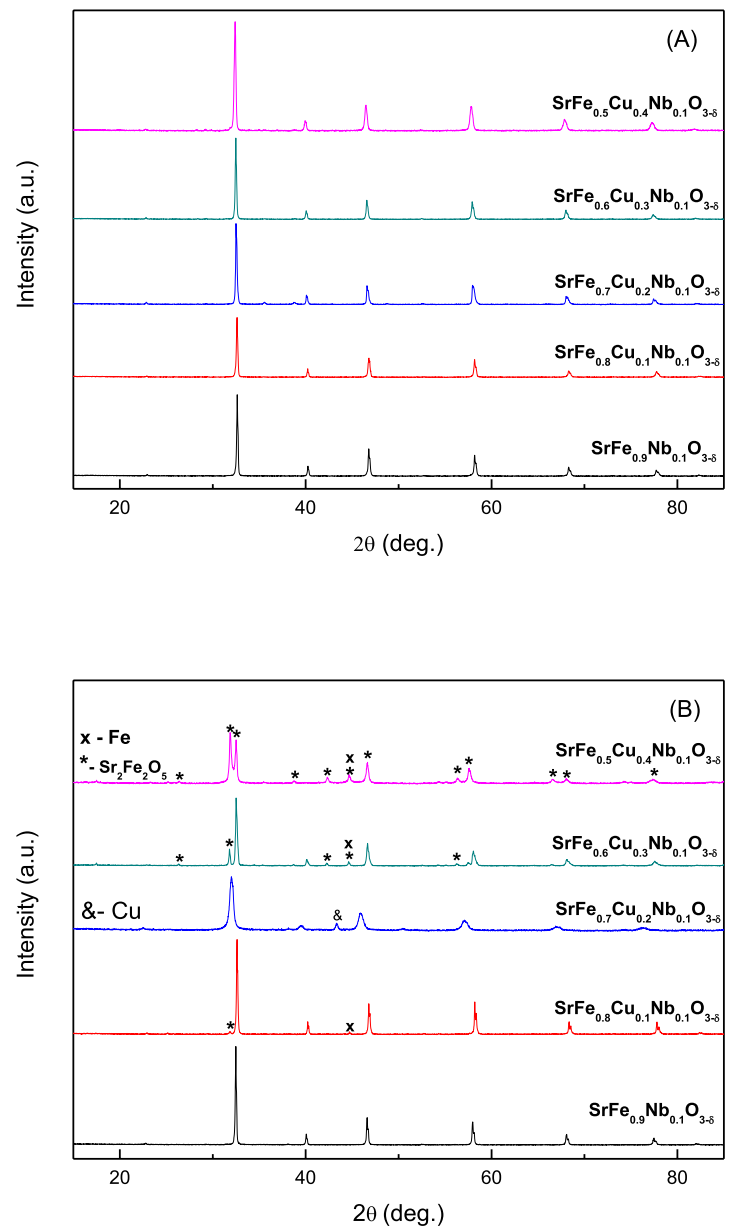

Figure 1. Room temperature $\mathrm{X}$-ray diffraction patterns of $\mathrm{SrFe}_{0.9-\mathrm{x}} \mathrm{Cu}_{\mathrm{x}} \mathrm{Nb}_{0.1} \mathrm{O}_{3-\delta}(\mathrm{x}=0-0.4)(\mathrm{x}=0-0.4)$ after obtained in air (A) and after further reduction in $5 \% \mathrm{H}_{2} / \mathrm{Ar}$ at $700^{\circ} \mathrm{C}$ for 10 hours (B).

Anikina et al. investigated the conductivity of $\mathrm{SrFe}_{1-\mathrm{x}} \mathrm{Nb}_{\mathrm{x}} \mathrm{O}_{3-\delta}$, where $\mathrm{x}=0.05,0.1,0.2,0.3,0.4$ and it was found $\mathrm{SrFe}_{0.9} \mathrm{Nb}_{0.1} \mathrm{O}_{3-\delta}$ exhibits the highest conductivity in a reducing atmosphere. However, the conductivity is still below $1 \mathrm{~S} / \mathrm{cm}$ at temperatures below $800^{\circ} \mathrm{C}^{21}$. In this study, we re-investigated the conductivity of $\operatorname{SrFe}_{0.9} \mathrm{Nb}_{0.1} \mathrm{O}_{3-\delta}$ finding that its conductivity in a reducing atmosphere was $\sim 30 \mathrm{~S} / \mathrm{cm}$ which is much higher than the reported values. It was also found that partial replacement of $\mathrm{Fe}$ by $\mathrm{Cu}$ in $\mathrm{SrFe}_{0.9} \mathrm{Nb}_{0.1} \mathrm{O}_{3-\delta}$ can further increase the conductivity in a reducing atmosphere. The perovskite oxide $\mathrm{SrFe}_{0.8} \mathrm{Cu}_{0.1} \mathrm{Nb}_{0.1} \mathrm{O}_{3-\delta}(\mathrm{SFCN})$ exhibits a conductivity of $63 \mathrm{Scm}^{-1}$ and $60 \mathrm{Scm}^{-1}$ at $415^{\circ} \mathrm{C}$ in air and $5 \% \mathrm{H}_{2} / \mathrm{Ar}$ respectively. To the best of our knowledge, the conductivity of $\mathrm{SrFe}_{0.8} \mathrm{Cu}_{0.1} \mathrm{Nb}_{0.1} \mathrm{O}_{3-\delta}$ in a reducing atmosphere is the highest among reported oxide anodes for SOFCs which also exhibit a high conductivity in air. A SOFC using $\mathrm{SrFe}_{0.8} \mathrm{Cu}_{0.1} \mathrm{Nb}_{0.1} \mathrm{O}_{3-\delta}$ as the anode and $\mathrm{La}_{0.8} \mathrm{Sr}_{0.2} \mathrm{FeO}_{3-\delta}$ as the cathode has been fabricated with a good performance in hydrogen achieved at temperatures below $700^{\circ} \mathrm{C}$.

Structure of New Oxides $\mathrm{SrFe}_{0.9-\mathrm{x}} \mathrm{Cu}_{\mathrm{x}} \mathrm{Nb}_{0.1} \mathrm{O}_{3-\delta}(\mathrm{x}=\mathbf{0 - 0 . 4 )}$

$\mathrm{X}$-ray diffraction of $\mathrm{SrFe}_{0.9-\mathrm{x}} \mathrm{Cu}_{\mathrm{x}} \mathrm{Nb}_{0.1} \mathrm{O}_{3-\delta}(\mathrm{x}=0-0.4)$ showed that it exhibited a single phase cubic perovskite structure (SG: $P m-3 m$ ) for all compounds (Figure S1). The XRD pattern of the $\mathrm{SrFe}_{0.8} \mathrm{Cu}_{0.1} \mathrm{Nb}_{0.1} \mathrm{O}_{3-\delta}$ sample is shown in Fig. 1A. The increase in the copper content significantly reduced the sintering temperature of the material, with the formation of a single phase perovskite structure that was not observed for $\mathrm{SrFe}_{0.4} \mathrm{Cu}_{0.5} \mathrm{Nb}_{0.1} \mathrm{O}_{3-\delta}$. Reitveld refinement of the structure using GSAS 22 demonstrated a pseudo-linear increase in the lattice parameters with increased copper doping up to $\mathrm{SrFe}_{0.6} \mathrm{Cu}_{0.3} \mathrm{Nb}_{0.1} \mathrm{O}_{3-\delta}$ (Figure S3 and Table S2). The increase in lattice parameters with increasing copper content can be attributed to the larger ionic radius of copper compared to iron $\left(\mathrm{Cu}^{2+} 0.73 \AA \text {, } \mathrm{Fe}^{3+} 0.645 \AA \text {, } \mathrm{Fe}^{4+} 0.585 \AA\right)^{23}$. Samples $\mathrm{SrFe}_{0.6} \mathrm{Cu}_{0.3} \mathrm{Nb}_{0.1} \mathrm{O}_{3-\delta}$ and $\mathrm{SrFe}_{0.5} \mathrm{Cu}_{0.4} \mathrm{Nb}_{0.1} \mathrm{O}_{3-\delta}$ exhibit similar lattice parameters whilst no impurity peaks can be observed on the XRD patterns, this is thought to be due to the proximity of the solid solution limit. Therefore the limit for achieving single phase in the $\mathrm{SrFe}_{0.9-\mathrm{x}} \mathrm{Cu}_{\mathrm{x}} \mathrm{Nb}_{0.1} \mathrm{O}_{3-\delta}$ series lies at $\mathrm{x} \leq 0.5$. The SEM picture of $\mathrm{SrFe}_{0.8} \mathrm{Cu}_{0.1} \mathrm{Nb}_{0.1} \mathrm{O}_{3-\delta}$ prepared by the solid state reaction method is shown in Fig. 2A.

Thermogravimetric analysis of $\mathrm{SrFe}_{0.9-\mathrm{x}} \mathrm{Cu}_{\mathrm{x}} \mathrm{Nb}_{0.1} \mathrm{O}_{3-\delta}(\mathrm{x}=0-0.4)$ in air showed a minor total loss in weight for all compounds, between $0.2 \mathrm{wt} \%$ and $0.5 \mathrm{wt} \%$, with no observable trend on increasing the dopant level, (Figure S3A). Accelerated weight loss was observed for all compounds on heating between 500 and $800^{\circ} \mathrm{C}$, with the weight loss noted to be reversible upon cooling. This acceleration in weight loss is likely to be the result of oxygen loss 

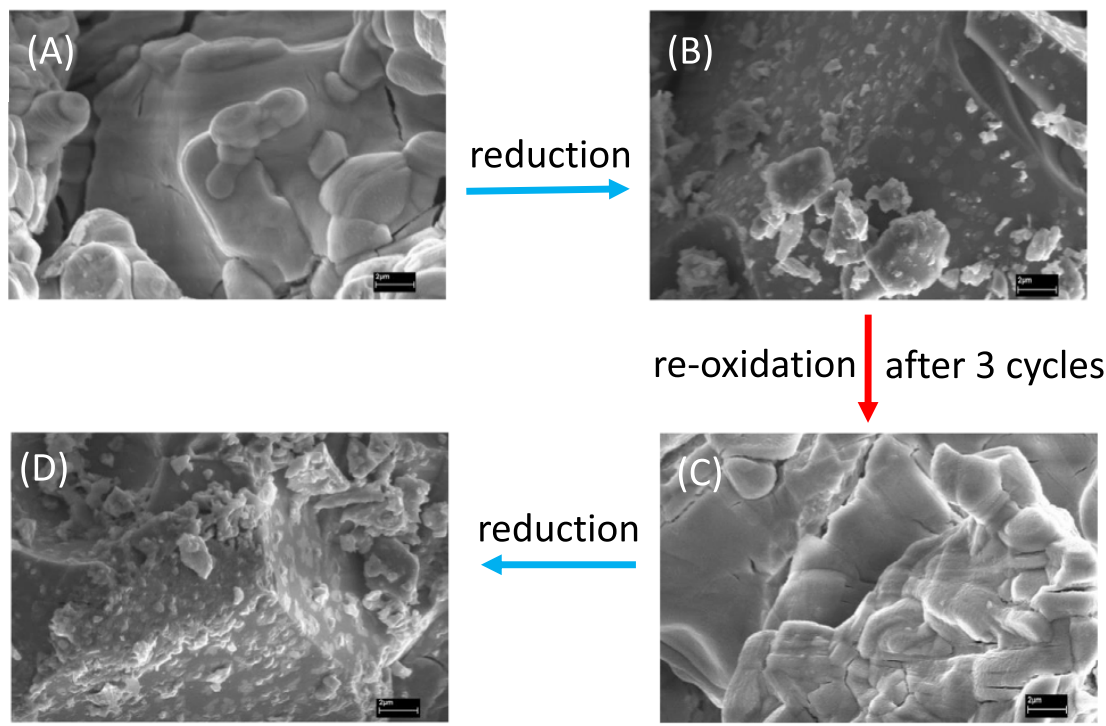

Figure 2. SEM pictures of sample $\mathrm{SrFe}_{0.8} \mathrm{Cu}_{0.1} \mathrm{Nb}_{0.1} \mathrm{O}_{3-\delta}$ powders after obtained in air (A); after further reduction in $5 \% \mathrm{H}_{2} / \mathrm{Ar}$ at $700^{\circ} \mathrm{C}$ for 10 hours (B); after further xoidise in air at $1300^{\circ} \mathrm{C}$ for 15 hours then reduce at $700{ }^{\circ} \mathrm{C}$ in $5 \% \mathrm{H}_{2} / \mathrm{Ar}$ for 10 hours ( 3 cycles with final step of reoxidation) (C) and futher reduction in $5 \% \mathrm{H}_{2} / \mathrm{Ar}$ at $700^{\circ} \mathrm{C}$ for 10 hours (D).

through high temperature reduction. Differential scanning calorimetry, Figure S3B, exhibits a reversible transition for all copper doped compounds, between $600^{\circ} \mathrm{C}$ and $670^{\circ} \mathrm{C}$ on heating and between $670{ }^{\circ} \mathrm{C}$ and $590^{\circ} \mathrm{C}$ on cooling which could be related to high temperature phase transition ${ }^{24}$.

\section{Conductivity of New Oxides $\mathrm{SrFe}_{0.9-x} \mathrm{Cu}_{\mathbf{x}} \mathrm{Nb}_{0.1} \mathrm{O}_{3-\delta}(\mathbf{x}=\mathbf{0 - 0 . 4 )}$ in Air}

The conductivity of the electrode materials is a key parameter to consider when evaluating their use in SOFCs. Whilst minimal copper doping, forming $\mathrm{SrFe}_{0.8} \mathrm{Cu}_{0.1} \mathrm{Nb}_{0.1} \mathrm{O}_{3-\delta}$, elicits a significant increase in conductivity in air over $\mathrm{SrFe}_{0.9} \mathrm{Nb}_{0.1} \mathrm{O}_{3-\delta}$, additional copper doping is observed to reduce the conductivity of the materials, although increasing dopant levels do not elicit a linear response in the reduction in conductivity (Fig. 3A). The introduction of $\mathrm{Cu}^{2+}$ dopant is expected to increase the average charge of iron in the sample with the proportion of $\mathrm{Fe}^{4+}$ ions, increasing the number of charge carriers and thus, in theory, increasing the conductivity ${ }^{25}$. Assuming that the copper dopant does not directly contribute to electronic conduction, the increase in the charge carrier concentration is only proportional to the iron content of the compound, which reduces with increasing $\mathrm{Cu}^{2+}$ dopant concentration. Thus at higher $\mathrm{Cu}^{2+}$ dopant concentrations the increase in charge carriers through the average charge of iron increasing is outweighed by the reduction in charge carriers through the reduction of the iron content leading to reduced conductivity. On the conductivity curves, a semiconductor-metal transition was observed for all compounds, with an increase in the transition temperature noted with increasing copper dopant levels (Fig. 3A). This transition has been observed previously for strontium ferrites, with Poulsen et al. ${ }^{26}$ suggesting that compound reduction at high temperature, resulting in a reduction in the charge carriers, was the cause of the transition. A pseudo-linear reduction in the oxygen content of strontium ferrite in air above $400{ }^{\circ} \mathrm{C}$ with increasing temperature, which would appear to confirm compound reduction at these temperatures, was observed previously ${ }^{27}$. The increase in the conductivity with increasing temperature was determined by Patrakeev et al. to be offset by the reduction in charge carrier concentration, causing an overall reduction in the electronic conductivity with increasing temperature, resulting in the pseudo-metallic behaviour ${ }^{28}$.

Stability of New Oxides $\mathrm{SrFe}_{0.9-\mathrm{x}} \mathrm{Cu}_{\mathbf{x}} \mathrm{Nb}_{0.1} \mathrm{O}_{3-\delta}(\mathbf{x}=\mathbf{0 - 0 . 4 )}$

In order to investigate the stability of $\mathrm{SrFe}_{0.9-\mathrm{x}} \mathrm{Cu}_{\mathrm{x}} \mathrm{Nb}_{0.1} \mathrm{O}_{3-\delta}(\mathrm{x}=0-0.4)$ in a reducing atmosphere, STA analyses in $5 \% \mathrm{H}_{2} / \mathrm{Ar}$ was carried out on the samples. The observed weight loss upon reduction of $\mathrm{SrFe}_{0.9-\mathrm{x}} \mathrm{Cu}_{\mathrm{x}} \mathrm{Nb}_{0.1} \mathrm{O}_{3-\delta}$ $(\mathrm{x}=0-0.4)$ varies between $2.6 \%$ and 3.3\%, with no observed trend with increasing dopant concentration (Figure S4A). Differential scanning calorimetry exhibits non-reversible transitions on heating for all compounds between $600^{\circ} \mathrm{C}$ and $670^{\circ} \mathrm{C}$, associated with cationic reduction (Figure S4B ${ }^{20}$. With the increase of copper dopant, the exothermic peaks happened at lower temperature indicating the reduction at lower temperature thus they are likely less stable, this has been confirmed by the $\mathrm{XRD}$ study (Fig. $1 \mathrm{~B}$ ). After reducing in $5 \% \mathrm{H}_{2} / \mathrm{Ar}$ at $700{ }^{\circ} \mathrm{C}$ for 10 hours, it was found that the $\mathrm{Cu}$-free sample $\mathrm{SrFe}_{0.9} \mathrm{Nb}_{0.1} \mathrm{O}_{3-\delta}$ was redox stable. For sample $\mathrm{SrFe}_{0.8} \mathrm{Cu}_{0.1} \mathrm{Nb}_{0.1} \mathrm{O}_{3-\delta}$, the majority of the phase is perovskite whilst an extra peak at $\sim 45$ degree was observed which belongs to the strongest (110) peak of $\alpha$-Fe (PDF: 6-696) after the reduction at $700{ }^{\circ} \mathrm{C}^{29}$. The formation of a Fe-rich FeCu alloy cannot be ruled out but the $\mathrm{Cu}$ content must be very low otherwise the peak should shift to a higher $\mathrm{d}$-spacing. The exsolution of metal particles is further confirmed by SEM observation where a small particle of iron was exsolved on the surface after the reduction (Fig. $2 \mathrm{~B}$ ). The very weak peak at $\sim 32.5^{\circ}$ could be a peak for a solid solution based on $\mathrm{Sr}_{2} \mathrm{Fe}_{2} \mathrm{O}_{5+\delta}$ parent phase ${ }^{30}$. When $\mathrm{x}$ is increased to 0.2 , the majority of sample $\mathrm{SrFe}_{0.7} \mathrm{Cu}_{0.2} \mathrm{Nb}_{0.1} \mathrm{O}_{3-\delta}$ is possibly $\mathrm{Sr}_{2} \mathrm{Fe}_{2} \mathrm{O}_{5+\delta}$ solid solution while an extra peak at $\sim 43^{\circ}$ was observed which could be the strongest peak 

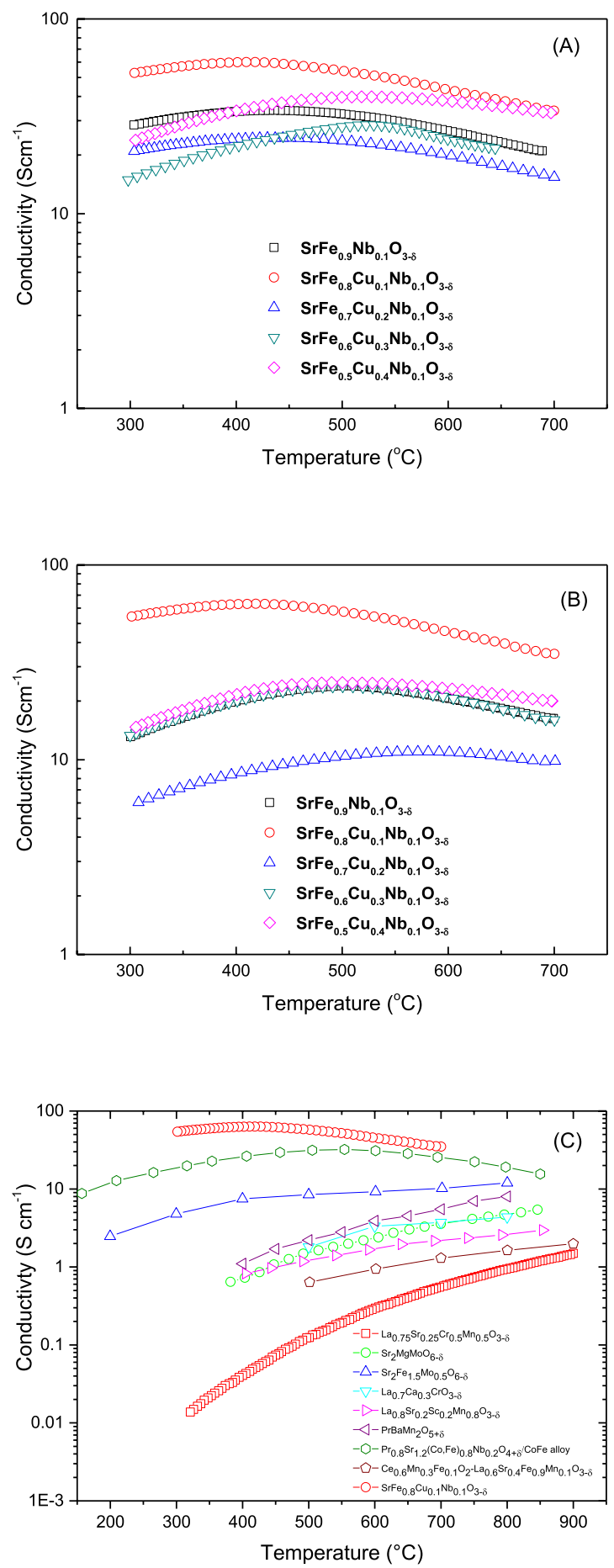

Figure 3. Conductivity of $\mathrm{SrFe}_{0.9-\mathrm{x}} \mathrm{Cu}_{\mathrm{x}} \mathrm{Nb}_{0.1} \mathrm{O}_{3-\delta}(\mathrm{x}=0-0.4)$ in air (A) $5 \% \mathrm{H}_{2} / \mathrm{Ar}(\mathbf{B})$ and comparison of conductivities of reported anode materials in $\mathrm{H}_{2}$ or $5 \% \mathrm{H}_{2}(\mathbf{C})$.

of $\mathrm{Cu}(\mathrm{Fm}-3 m)^{31}$. Again, formation of a Cu-rich $\mathrm{FeCu}$ alloy is also possible with the presence of $\mathrm{Fe}$ at the B-site of the perovskite phase. At $\mathrm{x}=0.3,0.4, \mathrm{Sr}_{2} \mathrm{Fe}_{2} \mathrm{O}_{5+\delta}$ based solid solution is the major phase with the Fe or Fe-rich alloy also present. The exsolution of metal seems strongly related to the composition, which will require further investigation. To exam whether the exsolution of metal is reversible, the reduced $\mathrm{SrFe}_{0.8} \mathrm{Cu}_{0.1} \mathrm{Nb}_{0.1} \mathrm{O}_{3-\delta}$ sample was re-oxidised in air at $1300{ }^{\circ} \mathrm{C}$ for 15 hours then further reducing in $5 \% \mathrm{H}_{2} / \mathrm{Ar}$ at $700{ }^{\circ} \mathrm{C}$ for 10 hours and stop at the re-oxidation stage after 3 cycles. It was observed that the exsolved metal was 'adsorbed' back after re-oxidation ii air at high temperature (Fig. 2C) while it was exsolved out after further reduction in $5 \% \mathrm{H}_{2} / \mathrm{Ar}$ at $700^{\circ} \mathrm{C}$ for 10 hours (Fig. 2D). This indicate the process for exsolved metal is reversible as observed in other oxides ${ }^{32,33}$. 


\section{Conductivity of New Oxides $\mathrm{SrFe}_{0.9-x} \mathrm{Cu}_{x} \mathrm{Nb}_{0.1} \mathrm{O}_{3-\delta}(x=0-0.4)$ in $5 \% \mathrm{H}_{2} / \mathrm{Ar}$}

To measure the conductivity in a reducing atmosphere, the $\mathrm{SrFe}_{0.9-\mathrm{x}} \mathrm{Cu}_{\mathrm{x}} \mathrm{Nb}_{0.1} \mathrm{O}_{3-\delta}$ pellets were coated with silver electrodes on both sides then reduced in $5 \% \mathrm{H}_{2} / \mathrm{Ar}$ at $700{ }^{\circ} \mathrm{C}$ for 10 hours (Fig. 3B). The conductivity was measured in $5 \% \mathrm{H}_{2} / \mathrm{Ar}$ on cooling. The highest conductivity for the samples measured was found to be for the $\mathrm{SrFe}_{0.8} \mathrm{Cu}_{0.1} \mathrm{Nb}_{0.1} \mathrm{O}_{3-\delta}$ sample with a conductivity of about $30-60 \mathrm{~S} / \mathrm{cm}$, in a reduced atmosphere. This is possibly due to the presence of exsolved Fe particles leading to increased electronic conductivity thus the total conductivity was also high. The lowest conductivity was observed for sample $\mathrm{SrFe}_{0.7} \mathrm{Cu}_{0.2} \mathrm{Nb}_{0.1} \mathrm{O}_{3-\delta}$, due to the $\mathrm{Sr}_{2} \mathrm{Fe}_{2} \mathrm{O}_{5+\delta}$ based solid solution being the major phase. This indicates that the conductivity of $\mathrm{Sr}_{2} \mathrm{Fe}_{2} \mathrm{O}_{5+\delta}$ based solid solution is lower than the primitive perovskite oxide based on $\mathrm{SrFeO}_{3-\delta}$. When $\mathrm{x}$ increased to 0.3 and 0.4 , the intensity of the peak at $\sim 45^{\circ}$ which represents the exsolved $\mathrm{Fe}$ is obviously stronger than that for sample $\mathrm{SrFe}_{0.8} \mathrm{Cu}_{0.1} \mathrm{Nb}_{0.1} \mathrm{O}_{3-\delta}$ (Fig. 1B) even though the major phase was the $\mathrm{Sr}_{2} \mathrm{Fe}_{2} \mathrm{O}_{5+\delta}$ based solid solution. The conductivity of $\mathrm{SrFe}_{0.6} \mathrm{Cu}_{0.3} \mathrm{Nb}_{0.1} \mathrm{O}_{3-\delta}$ is comparable to that for the $\mathrm{Cu}$-free sample $\mathrm{SrFe}_{0.9} \mathrm{Nb}_{0.1} \mathrm{O}_{3-\delta}$ whilst the conductivity of sample $\mathrm{SrFe}_{0.5} \mathrm{Cu}_{0.4} \mathrm{Nb}_{0.1} \mathrm{O}_{3-\delta}$ is slightly higher (Fig. 3B) due to higher concentration of exsolved $\mathrm{Fe}$ (or Fe-rich alloy). In the investigated oxides, in terms of both redox stability and conductivity, sample $\mathrm{SrFe}_{0.8} \mathrm{Cu}_{0.1} \mathrm{Nb}_{0.1} \mathrm{O}_{3-\delta}$ is the best.

For comparison, the conductivity of sample $\mathrm{SrFe}_{0.8} \mathrm{Cu}_{0.1} \mathrm{Nb}_{0.1} \mathrm{O}_{3-\delta}$ in a reducing atmosphere is plotted together with the reported best oxide anodes for SOFCs (Fig. 3C). It is the highest among the reported materials with reasonably high conductivity in air and a conductivity two times greater than that of the $\operatorname{Pr}_{0.8} \mathrm{Sr}_{1.2}(\mathrm{Co}, \mathrm{Fe})_{0.8} \mathrm{Nb}_{0.2} \mathrm{O}_{4+\delta} /$ $\mathrm{CoFe}$ alloy ${ }^{14}$. The conductivities of all other reported oxide anode materials in a reducing atmosphere are lower than $30 \mathrm{~S} / \mathrm{cm}$. This is clearly shown when the conductivity is plotted at absolute value (Figure S5). High conductivity is very important for SOFCs due to some designs involving long pathways for electrons at the electrode. Both SFCN and $\mathrm{Pr}_{0.8} \mathrm{Sr}_{1.2}(\mathrm{Co}, \mathrm{Fe})_{0.8} \mathrm{Nb}_{0.2} \mathrm{O}_{4+\delta} / \mathrm{CoFe}$ alloy have exsolved metal under reduction indicating that designing a material with exsolved metal under reduction will help to achieve a high conductivity in a reducing atmosphere. The exsolved metal may also improve the catalytic activity under the fuel cell operating conditions ${ }^{34,35}$.

\section{Fuel Cell Performance when $\mathrm{SrFe}_{0.8} \mathrm{Cu}_{0.1} \mathrm{Nb}_{0.1} \mathrm{O}_{3-\delta}$ Was Used as the Anode}

Solid oxide fuel cells with a $\mathrm{SrFe}_{0.8} \mathrm{Cu}_{0.1} \mathrm{Nb}_{0.1} \mathrm{O}_{3-\delta}$ anode, YSZ electrolyte and $\mathrm{La}_{0.8} \mathrm{Sr}_{0.2} \mathrm{FeO}_{3-\delta}$ cathode were fabricated. The performance and the corresponding A.C. impedance spectra of hydrogen/air fuel cell at different temperatures are shown in Fig. 4A,B. Good fuel cell performance with a power density of $423 \mathrm{~mW} / \mathrm{cm}^{2}$ was observed at $700{ }^{\circ} \mathrm{C}$. The total polarisation resistance of the electrode at $700{ }^{\circ} \mathrm{C}$ was only $0.25 \Omega \mathrm{cm}^{2}$ indicating $\mathrm{SrFe}_{0.8} \mathrm{Cu}_{0.1} \mathrm{Nb}_{0.1} \mathrm{O}_{3-\delta}$ performs well as an anode for SOFCs. However, a small amount of $\mathrm{Ru} / \mathrm{CeO}_{2}$ was introduced to improve the catalytic activity. For comparison, a SOFC with the same electrolyte and cathode was assembled with the $\mathrm{Cu}$-free anode $\mathrm{SrFe}_{0.9} \mathrm{Nb}_{0.1} \mathrm{O}_{3-\delta}$ used instead of the $\mathrm{Cu}$ doped anode. As shown in Fig. 4C,D, the highest power density at $700{ }^{\circ} \mathrm{C}$ was $372 \mathrm{~mW} / \mathrm{cm}^{2}$ which was slightly lower than that for a SOFC with $\mathrm{SrFe}_{0.8} \mathrm{Cu}_{0.1} \mathrm{Nb}_{0.1} \mathrm{O}_{3-\delta}$ anode. The total electrode polarisation was $0.30 \Omega \mathrm{cm}^{2}$ at $700^{\circ} \mathrm{C}$. The series resistance was $0.54 \Omega \mathrm{cm}^{2}$ which is also slightly higher than that of the cell where the $\mathrm{SrFe}_{0.8} \mathrm{Cu}_{0.1} \mathrm{Nb}_{0.1} \mathrm{O}_{3-\delta}$ anode was used $\left(0.50 \Omega \mathrm{cm}^{2}\right)$ (Fig. 4B,D). This indicates that the high conductivity of $\mathrm{SrFe}_{0.8} \mathrm{Cu}_{0.1} \mathrm{Nb}_{0.1} \mathrm{O}_{3-\delta}$ reduces both series and electrode polarisation resistances leading to high fuel cell performance. It should be noted that the exsolved Fe (or Fe rich $\mathrm{FeCu}$ alloy) at the $\mathrm{SrFe}_{0.8} \mathrm{Cu}_{0.1} \mathrm{Nb}_{0.1} \mathrm{O}_{3-\delta}$ anode may also improve the anode catalytic activity resulting in lower electrode polarisation resistance. The Arrhenius plot area-specific resistances (ASRs) for non-ohmic resistance of $\mathrm{SrFe}_{0.9} \mathrm{Nb}_{0.1} \mathrm{O}_{3-\delta}$ and $\mathrm{SrFe}_{0.8} \mathrm{Cu}_{0.1} \mathrm{Nb}_{0.1} \mathrm{O}_{3-\delta}$ anodes are shown in Figure $\mathrm{S} 6$. At $600^{\circ} \mathrm{C}$, the ASR for the two oxide anodes are similar but the ASR for $\mathrm{SrFe}_{0.8} \mathrm{Cu}_{0.1} \mathrm{Nb}_{0.1} \mathrm{O}_{3-\delta}$ is much lower at 650 and $700^{\circ} \mathrm{C}$ indicating better catalytic activity. Copper, copper alloy and iron alloy has been widely studied as excellent anode catalysts in SOFCs ${ }^{6,36-39}$. In an early reported, it was found that FeCo alloy was exsolved from $\mathrm{Pr}_{0.4} \mathrm{Sr}_{0.6} \mathrm{Co}_{0.2} \mathrm{Fe}_{0.7} \mathrm{Nb}_{0.1} \mathrm{O}_{3-\delta}$ anode while excellent fuel cell performance has been achieved although the conductivity of this material was not presented ${ }^{40}$.

\section{Conclusions}

In this work, a conductive perovskite oxide $\mathrm{SrFe}_{0.8} \mathrm{Cu}_{0.1} \mathrm{Nb}_{0.1} \mathrm{O}_{3-\delta}$ has been identified which exhibits the highest conductivity in a reducing atmosphere for oxides which also exhibit a high conductivity in air. This high conductivity is probably related to the exsolution of $\mathrm{Fe}$ (or Fe-rich FeCu alloy) during the high temperature reducing process. After the reduction, besides the exsolved metal, the major phase is that of the perovskite. Good performance at intermediate temperatures in solid oxide fuel cells using the $\mathrm{SrFe}_{0.8} \mathrm{Cu}_{0.1} \mathrm{Nb}_{0.1} \mathrm{O}_{3-\delta}$ based anode indicates that it is a promising anode for SOFCs. This study indicates that the conductivity of the oxides with exsolved metal is significantly high. This provides a strategy to identify a good material with high conductivity in both air and reducing atmospheres, i.e., starting from an oxide material with high conductivity in air, followed by introducing transition elements such as $\mathrm{Fe}, \mathrm{Co}, \mathrm{Ni}, \mathrm{Cu}$ in the lattice which may be exsolved from the lattice on reduction therefore resulting in high conductivity in a reducing atmosphere.

\section{Methods}

Synthesis of oxides. $\mathrm{SrFe}_{0.9-\mathrm{x}} \mathrm{Cu}_{\mathrm{x}} \mathrm{Nb}_{0.1} \mathrm{O}_{3-\delta}(\mathrm{x}=0-0.4)$ were synthesised by a sol-gel process, similar to previously reported processes ${ }^{20}$. A stoichiometric amount of $\mathrm{C}_{4} \mathrm{H}_{4} \mathrm{NNbO}_{9} \cdot \mathrm{xH}_{2} \mathrm{O}(99.9 \%$, Sigma Aldrich) was dissolved in distilled water. $\mathrm{H}_{2} \mathrm{O}_{2}$ was added to the niobium solution until a colour change was elicited. Citric acid $\left(99^{+} \%\right.$, Alfa Aesar), in a 2:1 molar ratio to the metal ions in the final product, was added and heated till a solution was formed. Stoichiometric amounts of $\mathrm{Sr}\left(\mathrm{NO}_{3}\right)_{2}\left(98 \%\right.$, Alfa Aesar), $\mathrm{Fe}\left(\mathrm{NO}_{3}\right)_{3} \cdot 9 \mathrm{H}_{2} \mathrm{O}(98 \%$, Alfa Aesar) and $\mathrm{Cu}\left(\mathrm{NO}_{3}\right)_{2} \cdot 2.5 \mathrm{H}_{2} \mathrm{O}$ (ACS grade, Alfa Aesar) were dissolved in distilled water. The solutions were mixed first then heated until gelation. The resultant gel formed was fired at $600^{\circ} \mathrm{C}$ for 2 hours and further fired at $1200-1300^{\circ} \mathrm{C}$ for 4-24 hours. The as-prepared powders were uniaxially pressed at $221 \mathrm{MPa}$ in to pellets $(\varnothing \approx 13 \mathrm{~mm} \times 2 \mathrm{~mm})$ and subsequently sintered in air at $1200^{\circ} \mathrm{C}-1450^{\circ} \mathrm{C}$ for $4-10$ hours. The details are listed in Table S1. 

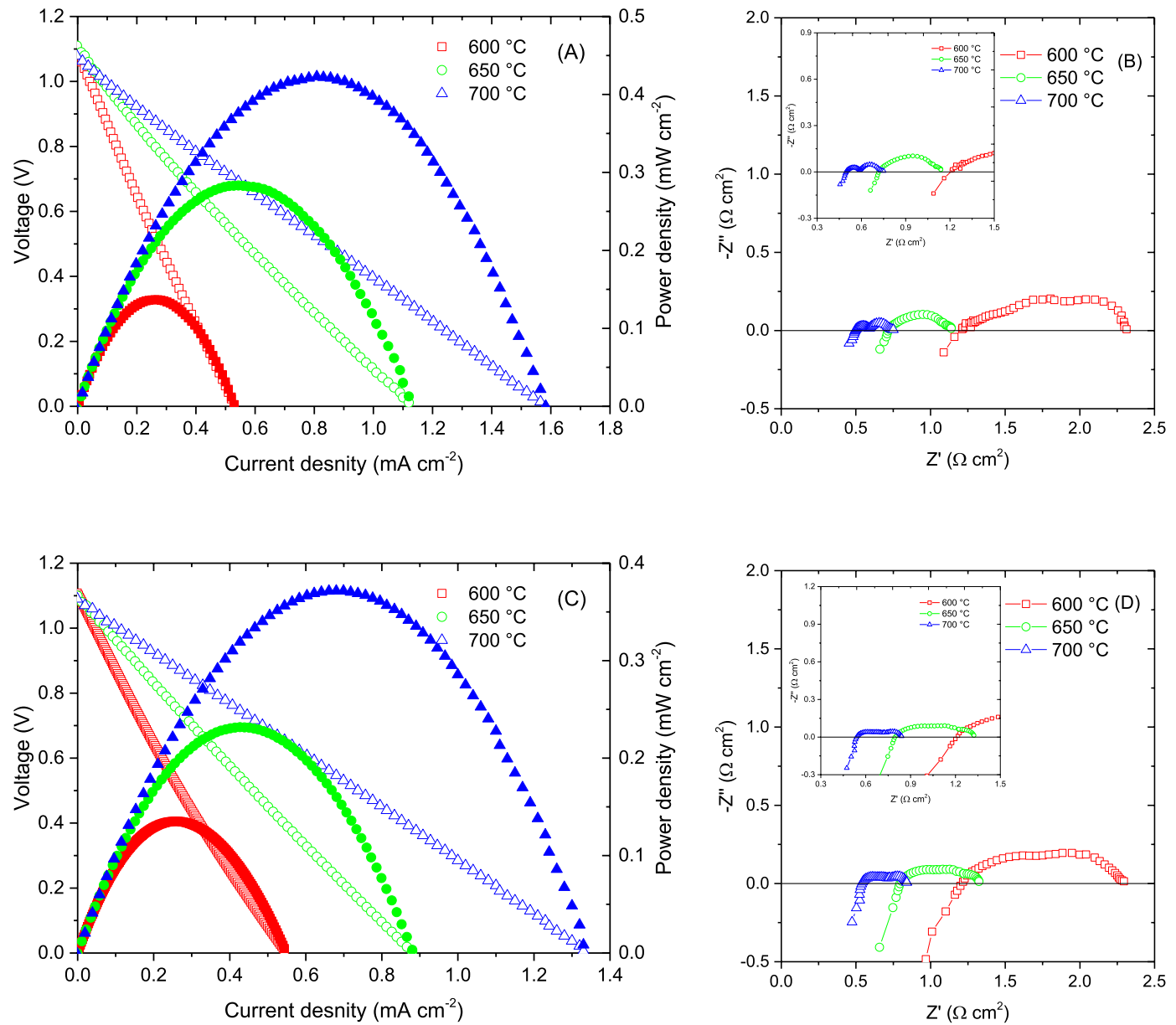

Figure 4. Fuel cell performance. Current-voltage curves $(\mathbf{A}, \mathbf{C})$ and impedance spectra $(\mathbf{B}, \mathbf{D})$ of solid oxide fuel cells with $\mathrm{SrFe}_{0.8} \mathrm{Cu}_{0.1} \mathrm{Nb}_{0.1} \mathrm{O}_{3-\delta}(\mathbf{A}, \mathbf{B})$ and $\mathrm{SrFe}_{0.9} \mathrm{Nb}_{0.1} \mathrm{O}_{3-\delta}(\mathbf{C}, \mathbf{D})$ anode.

Analytical Procedures. X-ray data was collected on a PANanalyticalX'Pert Pro in the Bragg-Brentano reflection geometry with a Ni-filtered $\mathrm{Cu} \mathrm{K \alpha}$ source (1.5405 $\AA$ ), fitted with a X'Celerator detector and an Empyrean CuLFF xrd tube. Absolute scans in the $2 \theta$ range of $5-100^{\circ}$ with step sizes of $0.0167^{\circ}$ were used during data collection. GSAS $^{22}$ software was used to perform a least squares refinement of the lattice parameters of all the samples.

Thermal analysis was conducted using a Stanton Redcroft STA 1500 Thermal Analyser on heating from room temperature to $800^{\circ} \mathrm{C}$ and on cooling from $800^{\circ} \mathrm{C}$ to room temperature in air, with a heating/cooling rate of $10^{\circ} \mathrm{C} / \mathrm{min}$, and in $5 \% \mathrm{H}_{2} / \mathrm{Ar}$, again with a heating/cooling rate of $10^{\circ} \mathrm{C} \mathrm{min}^{-1}$, and with a flow rate of $5 \% \mathrm{H}_{2} / \mathrm{Ar}$ of $50 \mathrm{mLmin}^{-1}$.

Scanning electron mircroscopy (SEM) measurements were carried out on a ZEISS SUPRA 55-VP Field Emission Scanning Electron Microscope. The densities of the pellets were determined from the measured mass and volume. Theoretical densities were calculated using experimental lattice parameters and the chemical formula $\mathrm{SrFe}_{0.9-\mathrm{x}} \mathrm{Cu}_{\mathrm{x}} \mathrm{Nb}_{0.1} \mathrm{O}_{3-\delta}(\mathrm{x}=0-0.4)$. The relative density of the pellets was $80-90 \%$ for all compounds.

Conductivity Testing. The pellets $(\varnothing \approx 13 \mathrm{~mm} \times 2 \mathrm{~mm})$ were coated on opposing sides using silver paste for all samples. The conductivity of the samples was measured primarily in air between $300^{\circ} \mathrm{C}$ to $700{ }^{\circ} \mathrm{C}$. Secondary measurements over the same temperature range were conducted in $5 \% \mathrm{H}_{2} /$ Ar following an equilibration step of 10 hours at $700^{\circ} \mathrm{C}$ in $5 \% \mathrm{H}_{2} /$ Ar. Measurements were conducted using a pseudo four-terminal DC method using a SolartronCell 1470E electrochemical interface controlled by CellTest software with an applied current of $1-0.1 \mathrm{~A}$.

Fuel Cell Fabrication and Testing. The electrolyte support cell used in this study was prepared through a tape casting process, with the outer two layers having pore formers. A dense YSZ slurry was prepared by mixing YSZ powder with methyl ethyl ketone and ethanol, and along with binders (polyvinyl butyral and polyethylene Glycol). Porous YSZ was prepared by adding YSZ powder with methyl ethyl ketone and ethanol, binders (polyvinyl butyral and polyethylene Glycol) and graphite (UCP-2 grade, Alfa Aesar) sequentially. The resultant two slurries were tape-casted separately. The porous-dense-porous YSZ structure was prepared by laminating three green tapes, followed by sintering at $1500^{\circ} \mathrm{C}$ for $4 \mathrm{~h}$, after which the porosity was approximately $65 \%$. The final thicknesses of the dense electrolyte and porous electrode were $\sim 100 \mu \mathrm{m}$ and $45 \mu \mathrm{m}$, respectively. The diameter of 
the porous YSZ region was $0.67 \mathrm{~cm}$. To prepare composites of SFN-YSZ and SFCuN-YSZ electrolyte supported cell, the precursor solutions were firstly prepared by dissolving nitrate salts of $\mathrm{Sr}, \mathrm{Fe}, \mathrm{Cu}$, and $\mathrm{Nb}$ in distilled water with the addition of quantitative amounts of citric acid. The SFCuN -YSZ anode was prepared by infiltrating the precursor aqueous solution into the anode side of the three-layered YSZ backbone. SFCuN was infiltrated into then porous YSZ backbone by a multi-step process followed by heating at $450{ }^{\circ} \mathrm{C}$ to decompose nitrates and citric acid. The infiltration process was repeated until $40 \mathrm{wt} \%$ loading of the oxide was achieved. Finally, SFCuN-YSZ anode wafers were calcined in air at $1000^{\circ} \mathrm{C}$. The $\mathrm{LSF}\left(\mathrm{La}_{0.8} \mathrm{Sr}_{0.2} \mathrm{FeO}_{3-\delta}\right)$-YSZ cathode was fabricated by infiltration using an aqueous solution of nitrate salts of $\mathrm{La}, \mathrm{Sr}$ and $\mathrm{Fe}$ on a porous $\mathrm{YSZ}$ backbone opposite the anode layer. This was then calcined in air at $850^{\circ} \mathrm{C} .2 \mathrm{wt} \% \mathrm{Ru}$ and $10 \mathrm{wt} \%$ ceria were also infiltrated into the anode and heated in air at $450^{\circ} \mathrm{C}$. For fuel cell performance tests, the cells were mounted on alumina tubes with ceramic adhesives (Ceramabond 552, Aremco). Ag paste and Ag wire were used for the electrical connections to both the anode and the cathode. The entire cell was placed inside a furnace and heated to the desired temperature. V-i polarization curves were measured using a Potentiostat in the temperature range of $700-600^{\circ} \mathrm{C}$. The fuel cell performance was measured by a Solartron 1470 e Electrochemical Interface coupled with a Solartron 1455 controlled by electrochemical software Solartron CellTest. The a.c. impedance was measured in the frequency range between $1 \mathrm{MHz}$ and $0.01 \mathrm{~Hz}$ at the amplitude of the a.c. signal $20 \mathrm{mV}$.

\section{References}

1. Steele, B. C. H. \& Heinzel, A. Materials for fuel-cell technologies. Nature 414, 345-352 (2001).

2. Graves, C., Ebbesen, S. D., Jensen, S. H., Simonsen, S. B. \& Mogensen, M. B. Eliminating degradation in solid oxide electrochemical cells by reversible operation. Nature Materials 14, 239-244 (2015).

3. Bastidas, D. M., Tao, S. W. \& Irvine, J. T. S. A symmetrical solid oxide fuel cell demonstrating redox stable perovskite electrodes. Journal of Materials Chemistrry 16, 1603-1605 (2006).

4. Carlos Ruiz-Morales, J., Canales-Vazquez, J., Pena-Martinez, J., Marrero-Lopez, D. \& Nunez, P. On the simultaneous use of $\mathrm{La}_{075} \mathrm{Sr}$ ${ }_{0.25} \mathrm{Cr}_{0.5} \mathrm{Mn}_{0.5} \mathrm{O}_{3}$-d as both anode and cathode material with improved microstructure in solid oxide fuel cells. Electrochimica Acta 52, 278-284 (2006).

5. Su, C., Wang, W., Liu, M., Tade, M. O. \& Shao, Z. Progress and prospects in symmetrical solid oxide fuel cells with two identical electrodes. Advanced Energy Materials 5, 1500188 (2015).

6. Cowin, P. I., Petit, C. T. G., Lan, R., Irvine, J. T. S. \& Tao, S. W. Recent progress in the development of anode materials for solid oxide fuel cells. Advanced Energy Materials 1, 314-332 (2011).

7. Tao, S. W. \& Irvine, J. T. S. A redox-stable efficient anode for solid-oxide fuel cells. Nature Materials 2, 320-323 (2003).

8. Huang, Y.-H., Dass, R. I., Xing, Z.-L. \& Goodenough, J. B. Double perovskites as anode materials for solid-oxide fuel cells. Science 312, 254-257 (2006).

9. Ruiz-Morales, J. C. et al. Disruption of extended defects in solid oxide fuel cell anodes for methane oxidation. Nature 439, 568-571 (2006).

10. Zheng, Y. et al. A new symmetric solid-oxide fuel cell with $\mathrm{La}_{0.8} \mathrm{Sr}_{0.2} \mathrm{Sc}_{0.2} \mathrm{Mn}_{0.8} \mathrm{O}_{3-8}$ perovskite oxide as both the anode and cathode. Acta Mater. 57, 1165-1175 (2009).

11. Zhang, Y., Zhou, Q. \& He, T. $\mathrm{La}_{0.7} \mathrm{Ca}_{0.3} \mathrm{CrO}_{3}-\mathrm{Ce}_{0.8} \mathrm{Gd}_{0.2} \mathrm{O}_{1.9}$ composites as symmetrical electrodes for solid-oxide fuel cells. J. Power Sources 196, 76-83 (2011).

12. Liu, Q., Dong, X. H., Xiao, G. L., Zhao, F. \& Chen, F. L. A novel electrode material for symmetrical SOFCs. Adv. Mater. 22, 5478-5482 (2010).

13. Wright, J. H., Virkar, A. V., Liu, Q. \& Chen, F. Electrical characterization and water sensitivity of $\mathrm{Sr}_{2} \mathrm{Fe}_{1.5} \mathrm{Mo}_{0.5} \mathrm{O}_{6-\delta}$ as a possible solid oxide fuel cell electrode. Journal of Power Sources 237, 13-18 (2013).

14. Yang, C. et al. Sulfur-tolerant redox-reversible anode material for direct hydrocarbon solid oxide fuel cells. Adv. Mater. 24, 1439-1443 (2012).

15. Sengodan, S. et al. Layered oxygen-deficient double perovskite as an effcient and stable anode for direct hydrocarbon solid oxide fuel cells. Nature Materials 14, 205-209 (2015).

16. Corre, G. et al. Activation and Ripening of Impregnated Manganese Containing Perovskite SOFC Electrodes under Redox Cycling. Chemistry of Materials 21, 1077-1084 (2009).

17. Shin, T. H., Ida, S. \& Ishihara, T. Doped $\mathrm{CeO}_{2}-\mathrm{LaFeO}_{3}$ composite oxide as an active anode for direct hydrocarbon-type solid oxide fuel cells. Journal of the American Chemical Society 133, 19399-19407 (2011).

18. Kazakevicius, E., Tsekouras, G., Michalow-Mauke, K. A., Kazlauskas, S. \& Graule, T. Electronic Conductivity Enhancement of ( $\mathrm{La}, \mathrm{Sr}) \mathrm{TiO}_{3}$ with Nb-Doping on B-Site. Fuel Cells 14, 954-960 (2014).

19. Cho, S. et al. Fe-substituted $\mathrm{SrTiO}_{3}$ d- $-\mathrm{Ce}_{0.9} \mathrm{Gd}_{0.1} \mathrm{O}_{2}$ composite anodes for solid oxide fuel cells. Energy Environ. Sci. 6, 1850-1857 (2013).

20. Cowin, P. I., Lan, R., Petit, C. T. G. \& Tao, S. W. Conductivity and redox stability of perovskite oxide $\mathrm{SrFe}_{1-\mathrm{x}} \mathrm{Ti}_{\mathrm{x}} \mathrm{O}_{3-\delta}(\mathrm{x} \leq 0.3)$. Solid State Sciences 46, 62-70 (2015).

21. Anikina, P. V., Markov, A. A., Patrakeev, M. V., Leonidov, I. A. \& Kozhevnikov, V. L. High-temperature transport and stability of $\mathrm{SrFe}_{1-\mathrm{x}} \mathrm{Nb}_{\mathrm{x}} \mathrm{O}_{3-}$ d. Solid State Sciences 11, 1156-1162 (2009).

22. Larson, A. C. \& Dreele, R. B. V. “General Structural Analysis System” Los Alamos National Laboratory Report LAUR, 86 (1994).

23. Shannon, R. D. Reised effective ionic-radii and systematic studies of interatomic distances in halides and chalcogenides. Acta Crystallographica Section A 32, 751-767 (1976).

24. Tao, S. W. \& Irvine, J. T. S. Phase transition in perovskite oxide $\mathrm{La}_{0.75} \mathrm{Sr}_{0.25} \mathrm{Cr}_{0.5} \mathrm{Mn}_{0.5} \mathrm{O}_{3-\delta}$ observed by in situ high-temperature neutron powder diffraction. Chemistry of Materials 18, 5453-5460 (2006).

25. Tao, S. W., Canales-Vazquez, J. \& Irvine, J. T. S. Structural and electrical properties of the perovskite oxide $\mathrm{Sr}_{2} \mathrm{FeNbO}_{6}$. Chemistry of Materials 16, 2309-2316 (2004)

26. Poulsen, F. W., Lauvstad, G. \& Tunold, R. Conductivity and seebeck measurements on strontium ferrates. Solid State Ionics 72, Part 2, 47-53 (1994).

27. Schmidt, M. \& Campbell, S. J. In situ neutron diffraction study $(300-127 \mathrm{~K})$ of non-stoichiometric strontium ferrite $\mathrm{SrFeO}_{x}$. Journal of Physics and Chemistry of Solids 63, 2085-2092 (2002).

28. Patrakeev, M. V. et al. Oxygen nonstoichiometry, conductivity, and seebeck coefficient of $\mathrm{La}_{0.3} \mathrm{Sr}_{0.7} \mathrm{Fe}_{1-\mathrm{x}} \mathrm{Ga}_{\mathrm{x}} \mathrm{O}_{2.65+\delta}$ perovskites. Journal of Solid State Chemistry 167, 203-213 (2002).

29. Xiong, Y. et al. Complexing-reagent assisted synthesis of a-Fe and $\mathrm{g}-\mathrm{Fe}_{2} \mathrm{O}_{3}$ nanowires under mild conditions. New Journal of Chemistry 27, 588-590 (2003).

30. Schmidt, M. \& Campbell, S. J. Crystal and magnetic structures of $\mathrm{Sr}_{2} \mathrm{Fe}_{2} \mathrm{O}_{5}$ at elevated temperature. Journal of Solid State Chemistry 156, 292-304 (2001). 
31. Suh, I. K., Ohta, H. \& Waseda, Y. High-temperature thermal-expansion of 6 metallic elements measured by dilatation method and X-ray-diffraction. J. Mater. Sci. 23, 757-760 (1988).

32. Li, S. S., Qin, Q. Q., Xie, K., Wang, Y. \& Wu, Y. C. High-performance fuel electrodes based on NbTi0.5M0.5O4 $(\mathrm{M}=\mathrm{Ni}, \mathrm{Cu})$ with reversible exsolution of the nano-catalyst for steam electrolysis. Journal of Materials Chemistry A 1, 8984-8993 (2013).

33. Gan, L. Z., Ye, L. T., Tao, S. W. \& Xie, K. Titanate cathodes with enhanced electrical properties achieved via growing surface Ni particles toward efficient carbon dioxide electrolysis. Physical Chemistry Chemical Physics 18, 3137-3143 (2016).

34. Neagu, D., Tsekouras, G., Miller, D. N., Menard, H. \& Irvine, J. T. S. In situ growth of nanoparticles through control of nonstoichiometry. Nature Chemistry 5, 916-923 (2013).

35. Neagu, D. et al. Nano-socketed nickel particles with enhanced coking resistance grown in situ by redox exsolution. Nat Commun 6, 8120 (2015).

36. Park, S., Vohs, J. M. \& Gorte, R. J. Direct oxidation of hydrocarbons in a solid-oxide fuel cell. Nature 404, 265-267 (2000).

37. Atkinson, A. et al. Advanced anodes for high-temperature fuel cells. Nat. Mater. 3, 17-27 (2004).

38. Tao, S. \& Irvine, J. T. S. Discovery and characterization of novel oxide anodes for solid oxide fuel cells. The Chemical Record 4, 83-95 (2004).

39. $\mathrm{Li}, \mathrm{K}$. et al. Methane on-cell reforming in nickel-iron alloy supported solid oxide fuel cells. Journal of Power Sources 284, 446-451 (2015).

40. Zhang, L. et al. Co-generation of electricity and chemicals from propane fuel in solid oxide fuel cells with anode containing nanobimetallic catalyst. Journal of Power Sources 262, 421-428 (2014).

\section{Acknowledgements}

The authors thank EPSRC Flame SOFCs (EP/K021036/2), UK-India Biogas SOFCs (EP/I037016/1) and SuperGen Fuel Cells (EP/G030995/1) projects for funding. One of the authors (Cowin) thanks ScotChem SPIRIT scheme for support of his $\mathrm{PhD}$ study.

\section{Author Contributions}

S.T. conceptualized the study. R.L. P.I.C. and S.T. wrote the paper and all other authors provided feedback. P.I.C. synthesised the materials and measured the conductivity and performed XRD analyses. R.L. collect the SEM pictures and assisted XRD phase analyses. S.S. collected the fuel cell performance data.

\section{Additional Information \\ Supplementary information accompanies this paper at http://www.nature.com/srep}

Competing financial interests: The authors declare no competing financial interests.

How to cite this article: Lan, R. et al. A perovskite oxide with high conductivities in both air and reducing atmosphere for use as electrode for solid oxide fuel cells. Sci. Rep. 6, 31839; doi: 10.1038/srep31839 (2016).

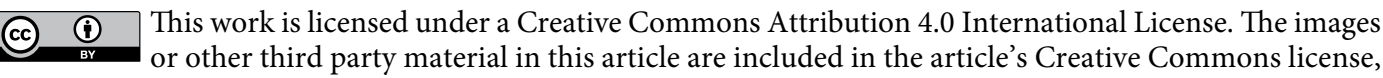
unless indicated otherwise in the credit line; if the material is not included under the Creative Commons license, users will need to obtain permission from the license holder to reproduce the material. To view a copy of this license, visit http://creativecommons.org/licenses/by/4.0/

(C) The Author(s) 2016 